Corporate branding's influence on front-line employee and consumer value co-creation in UK household consumer markets

\author{
Keith Glanfield \\ Aston Business School, Aston University, Birmingham, UK \\ K.Glanfield2@aston.ac.uk
}

Anna-Lena Ackfeldt

Aston Business School, Aston University, Birmingham, UK

A.Ackfeldt@aston.ac.uk

T C Melewar

Middlesex Business School, Middlesex University, Hendon, UK

$\underline{\text { T.C.Melewar@mdx.ac.uk }}$ 


\title{
Corporate branding's influence on front-line employee and consumer value co-creation in UK household consumer markets
}

\begin{abstract}
General Managers' are presented with an extensive opportunity to innovate and gain market advantage from front-line employees (FLEs) and consumers working together to exchange services and co-create value. To do this General Managers need to understand more about what influences the content and quality of FLE and consumer service exchanges? What predisposes FLEs to commit to service exchange and value co-creation? And what organisational phenomena can General Managers use to influence this predisposition? This paper presents results from an empirical research study of FLEs employed by a firm that provides installation, servicing and emergency services to domestic households across the UK. The study reveals the importance of the firm's corporate brand in its influence upon FLE's sense of membership and attachment to a firm (organisational identity) and the consequent effect of this on their pre-disposition for service exchange (organisational commitment), i.e. whether FLEs want to remain in their role because they feel they ought to, want to or they have too much to lose by leaving.
\end{abstract}

Keywords: corporate brand associations, organisational identity, organisational commitment, service exchange, value co-creation, S-D Logic 


\section{Corporate branding's influence on front-line employee and consumer value co-creation in UK household consumer markets}

\section{Introduction}

Firms who serve consumer markets, to a greater or lesser degree, have to balance managing the operational delivery of both products and services to consumers (Shostack, 1977). Some offerings hold a very large service component, e.g. servicing of household central heating systems. Others less so, e.g. the manufacture and sale of fast moving consumer goods (FMCG). Both examples, however, contain a form of service, even if this service is simply the interaction between a consumer and front-line employee (FLE) at point of sale e.g. purchase of a FMCG product at a supermarket check-out (Heskett et al., 1997). This important contact between FLEs and customers is referred to as a service encounter, and implies consumers passively consume a service provided by a FLE (Bitner et al., 1994). As service encounters influence customer satisfaction and loyalty (Evanschitzky et al., 2012), and impact a firm's profitability and growth (Homburg et al., 2009), it is important General Managers create an appropriate environment for the effective delivery of services.

This becomes even more important if service encounters are considered more than just one-way transactions, but an opportunity for FLEs and customers to exchange services and work together to co-create value (Vargo and Lusch, 2008). For example, turning the act of servicing a central heating system into a warm and cosy home for the consumer by a service engineer working with a house holder to set up their heating system to fit their daily routine. According to Service-Dominant Logic (S-D Logic), service is the fundamental basis of exchange for all firms and value is co-created by multiple social actors, which always includes a beneficiary who uniquely determines value (Lusch and Vargo, 2014). Actors, i.e. FLEs and customers, participate in the creation and offering of value by exchanging services 
(Chandler and Lusch, 2015). Again, this is contingent on General Managers creating an appropriate services environment. That is, a service environment that encourages service exchange and value co-creation (Chandler and Vargo, 2011).

S-D Logic encourages General Managers to think differently about their firms: as a place where value is co-created through a system of service exchanges, especially those that occur between FLEs and consumers (Greer et al, 2016). This change in emphasis offers General Managers an opportunity to innovate and gain market advantage through service exchange and value co-creation. For example, to use a simple household central heating service as an opportunity for the customer and engineer to talk through household energy usage and make a plan to reduce energy costs. However, to realise this potential, General Managers must address three potential gaps in their knowledge. First, what influences the content and quality of FLE and customer service exchanges? Second, what predisposes FLEs to commit to service exchange and value co-creation? Third, what organisational phenomena can General Managers use to influence this predisposition?

\section{Literature review}

\subsection{What influences the content and quality of FLEs actor-to-actor service exchanges?}

FLEs stay in their role, or commit to a course of action or objective, i.e. goals, programs and projects, because they either feel they ought to (normative commitment), want to (affective commitment), or feel they have too much to lose (continuance commitment) by severing the connection (Meyer and Allen, 1997). Meyer (2013) proposes these reasons for an FLE staying in their role, organisational commitment, as the primary influencer of the content and quality of FLE actor-to-actor exchanges in a multi-stakeholder environment. Of importance is affective commitment, followed by normative commitment (Meyer, 2013). 


\subsection{What predisposes FLEs to commit to service exchange and value co-creation?}

When at work, FLEs consider themselves not just as individuals but also as members of multiple social groups within the firm, e.g. a work team, a division, the firm or the firm's parent owner (Cornelissen et al., 2007; Homburg et al., 2011). This membership defines "who they are" at work in terms of the strength of attachment they have to specific groups, termed social identity (Taijfel and Turner, 1979), and, in particular, their attachment to the firm itself, termed organisational identity. This psychological attachment to the firm and its sub groupings is a pre-requisite for the retention of organisational commitment (Meyer et al., 2006).

\subsection{What organisational phenomena can General Managers use to influence this}

\section{predisposition?}

When working, on a day-to-day basis, FLEs are not constantly thinking about which groups they are members of and how strong their attachment to each is. To make this membership salient, they need reminders of their group membership from their working environment in the form of signal and cues (Turner et al., 1994). FLEs are daily surrounded by the firm's corporate brand (Brodie et al., 2009; Preece and Kerrigan, 2015), and interact with customers as members of the firm's brand community (Merz et al., 2009). Consequently, FLEs develop associations for the brand (Anderson and Bower, 1973) concerning "who are we as an organisation?" and "what do others think of the organisation?" (Brown et al., 2006 p. 102). These organisational and construed brand associations are likely to influence the organisational identity held by FLEs for both their host and parent organisations. 


\subsection{Hypothesis development}

In reviewing the relevant literature, this study proposes three hypotheses to address the central theme of the paper: corporate branding's influence on FLE and consumer service exchange and value co-creation:

Hypothesis 1: FLEs' organisational identification with the host and parent organisations positively influence their affective, normative and continuous commitment.

Hypothesis 2: FLEs' organisational and construed brand associations positively influence their organisational identification with the host and parent organisation. Hypothesis 3: FLEs' parent organisational identification positively influences FLEs' host organisational identification.

The hypotheses combine to form the study's conceptual model, see Figure 1.

\section{"Insert Figure 1 about here"}

\section{Method}

\subsection{Research design}

For this study, we used structural equation modelling (SEM) to assess the relationships between both forms of FLE brand associations and their respective host and parent organisational identification. Along with the relationships between both forms of identification and FLE affective, normative and continuous commitment (see Figure 1). 


\subsection{Population and sample}

Data was collected from FLEs in a large firm that provides installation, servicing and emergency services to domestic households across the UK. The firm directly competes with three distinct competitor groupings. Local small firms, who often compete on price. Regional firms, who have the capability to compete based on service exchange and value co-creation but, often, do not. National competitors, who have nationally established brands and, because of scale, find it difficult to create a consistent environment for FLEs to co-create value with consumers. Value co-creation, through FLE and consumer service exchanges, is, therefore, increasingly of importance to the subject firm. In this sector, technology, to an extent, provides a foundation on which FLEs and consumers are able to exchange services. It provides, for example, information on system efficiency and usage habits. However, this information is only of use if FLEs and consumers work through it together to identify potential problems and to co-create a solution. Hence, the importance of this research study. 260 FLEs in 20 work teams received a survey packet containing a cover letter from the research explaining the study and a self-completion questionnaire. The cover letter provided information about how to complete the survey, and explained that there were no right or wrong answer to the statements. Assurances were also made that respondents would remain anonymous. Thus, we designed the cover letter to control for common method bias (Podsakoff et al., 2003). To further reduce common method bias, the study's conceptual framework was not disclosed to respondents. Out of the 260 distributed survey packets, 145 usable questionnaires were returned, thus yielding an effective response rate of $56 \%$. 


\subsection{Measurement}

We used established measures from the marketing and organisation behaviour literature to measure the multi-item constructs in our study. All the constructs were measured on a 7-point Likert-type scale, anchored by 1 = "strongly disagree" and 7 = "strongly agree".

The six items measuring FLE construed brand associations and organisational brand associations were adapted from Yoo et al.'s (2000) brand equity items used to measure a brands perceived quality. The subject term of each of the scales six items were changed to

read "Customers consider ........" for construed brand associations and "I consider ........" for organisational brand associations. FLEs organisational identification with their host and parent organisation were measured by Mael and Ashforth's (1992) six-item scale that is commonly used in the social sciences. We used Allen and Meyer's (1990) scales to measure affective, normative and continuous commitment.

\section{Data analysis}

SEM is a method of multivariate data analysis (Diamantopoulos and Siguaw, 2000). The authors used co-variance SEM, because it is concerned with incrementally developing existing theory (Hair et al., 2010), to test the structure of the study's variables (confirmatory factor analysis) and to test estimate the statistical relationships between them (structural model) (Chin, 1998).

\section{Results}

\subsection{Demographics of respondents}

The descriptive analysis reveals that all respondents are FLEs with tenure from four years and under to up to over 25 years continuous service. $70.5 \%$ of respondents are male and $29.5 \%$ 
female, with ages ranging from below 20 years of age to 50+. See Table 1 for respondent demographics.

\section{"Insert Table 1 about here"}

\subsection{Statistical testing prior to measurement model estimation}

Before estimating the study's measurement model, the data was first successfully tested for non-response bias (Armstrong and Overton, 1977) and common method variance (Podsakoff et al., 2003) using the insertion of a surrogate measure into the measurement model (Lindell and Whitney, 2001).

\subsection{Measurement model}

5.3.1 Content validity. A confirmatory factor analysis was conducted using LISREL (Jöreskog and Sörbom, 1996) to assess the construct validity of the study's measurement scales (Hair et al., 2010). Table 2 shows the finalised items of the measurement model load highly and significantly onto the respective constructs these were designed to measure, thus, establishing content validity.

5.3.2 Measurement model estimation. The results of estimating the study's measurement model indicated a very good fit between it and the empirical data:

$$
\chi^{2}(384)=553.25, \mathrm{p}=.00 ; \mathrm{CFI}=.97 ; \mathrm{RMSEA}=.06 \text {. }
$$


Results exceed the thresholds set for Comparative Fit Index (CFI, >.92) and Root Means Square Error of Approximation (RMSEA, <.08) of a study with $>250$ respondents and $<30$ measurement items (Hair et al., 2010).

"Insert Table 2 about here"

Average variances extracted ranged from .51 to .93 (see Table 2) indicating scale reliability (Holmes-Smith, 2001). Composite reliability ranged from .81 to .93, exceeding the cut-off value of 0.70 (Steenkamp and van Trijp, 1991). Finally, the requirements for discriminant validity were also satisfied, see Table 3 (Fornell and Larcker, 1981).

\section{"Insert Table 3 about here"}

\subsection{Structural model}

5.4.1 Goodness-of-fit. LISREL (version 8.80), using maximum-likelihood estimation, was used to test the theoretical model. The goodness-of-fit measures indicated that the hypothesised model was a very good representation of the empirical data (Hair et al, 2010):

$$
\chi^{2}(393)=584.42, \mathrm{p}=0.00 ; \mathrm{CFI}=.97 ; \mathrm{RMSEA}=0.58
$$

Reported results exceeded the recognised threshold for both CFI (.92) and RMSEA $(<.08)$ in a study with $>250$ respondents and $<30$ measurement items (Hair et al., 2010).

5.4.2 Hypotheses testing. The study findings partly support Hypothesis 1, as both forms of organisational identification influence normative commitment, while individually they 
differed in their influence on affective and continuous commitment (See $\beta_{14,}, \beta_{24}, \beta_{25}$ and $\beta_{35}$ for $\mathrm{H} 1$ in Table 4). The influence of host organisational identification on affective and normative commitment is an important finding $\left(\beta_{14}, \beta_{24}\right)$.

Hypothesis 2 is partially supported by finding FLEs' construed and organisational brand associations only influence FLE organisational identification with the host organisation (See $\gamma_{41}, \gamma_{42}$ for $\mathrm{H} 2$ in Table 4$)$.

Finally, Hypothesis 3 is supported as organisational identification at the parent level positively influences the host organisation positively (See $\beta_{45}$ for H3 in Table 4).

"Insert Table 4 about here"

\section{Findings, implications for General Managers and further research}

The findings of this study hold two sets of implications for General Managers.

\subsection{The potential to influence FLE service exchange and value creation through corporate branding}

In practice, no matter whether it be super-market check-out staff or engineers who service central heating systems, FLEs interact with customers and all do so representing their employer's brand. This research indicates that not only do FLEs hold their own set of brand associations, it also demonstrates the power of day-to-day FLE and customer interaction in the forming of FLE's brand knowledge from a customer's perspective. FLEs, in construing the brand equity of customers, is a form of FLE and customer service exchange and cocreation. In order to be effective, it relies on FLEs and customers receiving consistent, rather than different and possibly conflicting, messages about a firm's brand. This research suggests 
that if General Managers manage their corporate brand in a consistent and holistic manner, instead of separating out internal and external brand messaging, it is much more likely for FLEs to develop a strong organisational identity and bond with the firm.

This means General Managers should ensure their firm's brand clearly communicates the purpose of the firm, what the firm stands for and what makes it unique and distinctive. Using the brand as a means of bringing together the firm's stakeholders, around a common purpose, to solve problems and issues by co-creating solutions. Along with communicating the benefits and potential possibilities of consumers and FLEs coming together, for mutual benefit, to share information and experiences.

\subsection{The importance of identification and commitment}

Managers, in managing groups of FLEs, at times likely observe some FLEs work well with customers in service exchanges, while others do not put in the effort needed to do this effectively. A simple example is some service engineers, when servicing heating systems, work with customers to tailor system settings to the habits of the household and some do not. Those who do not can often be characterised by managers as exhibiting "poor" behaviour and not "living the values" of the brand.

This research indicates FLEs do not solely consider themselves, purely, as individuals. The groups they consider they are members of i.e. the firm itself, its corporate parent, a division of the firm or a work team, influences their sense of who they are at work. General Managers can support their front-line manager's by helping them understand the importance of FLE group affiliation, how the brand can help to strengthen social identity with particular groups and what this means for their sense of commitment to service exchange and co-creation. 
This means a front-line manager understanding which group an FLE associates with the most enables them to re-inforce to an FLE how membership of that group, and what it stands for, supports working with consumers to co-create value. For example, if the firm's brand is considered as distinctive, holding cache and status, this can be deployed by managers to heighten the self-esteem of FLEs and remind them of the prestige consumers associate with the firm and it's brand. In doing so encouraging FLEs to share with consumers the prestige they associate with being a member of the firm and, by sharing and exchanging experiences, working with consumers for mutual value and benefit.

A strong sense of attachment with the firm, organisational identity, or a particular group within it, social identity, is important given it's influence on FLE organisational commitment. Front-line managers would, no doubt, rather have FLEs who want to be service engineers in the firm (affective commitment), or feel that they ought to be (normative commitment) rather than those who feel they have to be because they have too much to lose by leaving (continuous commitment). Especially as the two former forms of commitment, particularly affective commitment, positively influence FLE's positive pre-disposition for service exchange and co-creation with consumers. General Managers, by providing advice and guidance on how to understand FLEs commitment profiles, how they can be influenced via the firm's brand and what they mean for service exchange would assist front-line managers to move beyond making simplistic judgments about FLE service performance. Increasing the likelihood of effective FLE and customer service exchange and co-creation, whilst reducing the risk of service failure.

\subsection{Limitations and further research}

It is important to view the quantitative research findings of this study in the light of its limitations. The sample was from a UK-based domestic service organisation. This may not 
necessarily restrict, in broad terms, the study's generalizability to other service organisations, but it may restrict the generalizability of specific findings more widely. Given this, the research would benefit from further replication studies in other organisations and countries.

The authors recognise, however, that the study would benefit significantly from a complementary inductive qualitative study, which could help in understanding the broader phenomena that influence the social identities held by FLEs, and the spectrum and nature of their social identities. This would enable the authors to develop a deeper understanding of the individual applicability of specific FLE identities for service exchange and value co-creation. 


\section{References}

Allen, N.J. and John, P.M. (1990) The measurement and antecedents of affective, continuance and normative commitment to the organization. Journal of Occupational Psychology 63(1): 1-18.

Anderson, J.R. and Bower, G.H. (1973) Human Associative Memory: A Brief Edition. Hillside, NJ: Erlbaum.

Armstrong, J.S. and Overton, T.S. (1977) Estimating Nonresponse Bias in Mail Surveys. Journal of Marketing Research, XIV (August 1977): 396-402.

Bitner, M.J., Booms, B.H. and Mohr, L.A. (1994) Critical service encounters: The employee's viewpoint. Journal of Marketing, 58(4): 95-106.

Brodie, R.J., Whittome, J.R.M. and Brush, G.J. (2009) Investigating the service brand: A customer value perspective. Journal of Business Research, 62(3): 345-355.

Brown, T.J., Dacin, P.A., Pratt, M.G. and Whetten, D.A. (2006) Identity, Intended Image, Construed Image, and Reputation: An Interdisciplinary Framework and Suggested Terminology. Journal of the Academy of Marketing Science, 34(2): 99-106.

Chandler, J.D. and Lusch, R.F. (2015) Service Systems: A Broadened Framework and Research Agenda on Value Propositions, Engagement, and Service Experience, Journal of Service Research, 18(1): 6-22.

Chandler, J.D. and Vargo, S.L. (2011) Contextualizaion and Value-in-context: How Context Frames Exchange. Marketing Theory, 11(1): 35-49.

Chin, W. W. (1998) Issues and opinion on structural equation modelling. MIS Quarterly, Vol. 22(1): VII-XVI

Cornelissen, J.P., Haslam, S.A. and Balmer, J.M.T. (2007) Social Identity, Organizational Identity and Corporate Identity: Towards an Integrated Understanding of Processes, Patternings and Products. British Journal of Management, 18: 1-16. 
Evanschitzsky, H., Wagenheing, F. and Wünderlich, N. (2012) Perils of Managing the Service Profit Chain: The Role of Time Lags and Feedback Loops. Journal of Retailing, 88(3): 356-366.

Fornell, C. and Larcker, D.F. (1981) Structural Equation Models With Unobservable Variables and Measurement Error: Algebra and Statistics. Journal of Marketing Research, 18(3): 382-388.

Greer, C.R., Lusch, R.F. and Vargo, S.L. (2016) A service perspective: Ley managerial insights from service-dominant (S-D) logic. Organizational Dynamics, 45(1): 28-38.

Hair, J. F., Jr., Black, W.C. Babin, B.J. and Anderson, R.E. (2010) Multivariate Data Analysis: A Global Perspective. Upper Saddle River, NJ: Pearson.

Heskett, J.L., Sasser, W.E. Jr., and Schlesinger, L.A. (1997) The Service Profit Chain: How Leading Companies Link Profit and Growth to Loyalty, Satisfaction, and Value. New York: The Free Press.

Holmes-Smith, P. (2000) Introduction to Structural Equation Modelling. Canberra: Research, evaluation and measurement services.

Homburg, C., Wieseke, J. and Bornemann, T. (2009) Implementing the Marketing Concept at the Employee-Customer Interface: The Role of Customer Need Knowledge. Journal of Marketing, 73: 64-81.

Homburg, C., Wieseke, J., Lukas, B. and Mikolon, S. (2011) When salespeople develop negative headquarters stereotypes: performance effects and managerial remedies. Journal of the Academy of Marketing Science, 39(5): 664-682.

Jöreskog, K.G. and Sörbom, D. (1996) LISREL 8: User's Reference Guide. Chicago: Scientific Software International.

Lindell, M.K., and Whitney, D.J. (2001) Accounting for common method variance in crosssectional research designs. Journal of Applied Psychology, 86: 114-121. 
Lusch, R.F. and Vargo, S.L. (2014) Service-dominant logic: Promises, perspectives, and possibilities. Cambridge: Cambridge University Press.

Mael, F. and Ashforth, B.E. (1992) Alumni and their alma mater: A partial test of the reformulated model of organizational identification. Journal of Organizational Behavior, 13(2): 103-123.

Merz, M. A., Yi, H. and Vargo, S. L. (2009) The evolving brand logic: a service-dominant logic perspective. Journal of the Academy of Marketing Science, 37(3): 328-344.

Meyer, J.P. (2013) The science-practice gap and employee engagement: It's a matter of principle. Canadian Psychology, 54: 235-245.

Meyer, J.P. and Allen, N.J. (1997) Commitment in the workplace: Theory, research and application. Newbury Park, CA: Sage.

Meyer, J.P., Becker, T.E. and van Dick, R. (2006) Social identities and commitments at work: toward an integrative model. Journal of Organizational Behavior, 27(5): 665683.

Podsakoff, P.M., MacKenzie, S.B, Podsakoff, N.P. and Lee, J.-Y. (2003) Common Method Biases in Behavioral Research: A Critical Review of the Literature and Recommended Remedies. Journal of Applied Psychology, 88(5): 879-903.

Preece, C. and Kerrigan, F. (2015) Multi-stakeholder brand narratives: an analysis of the construction of artistic brands. Journal of Marketing Management, 31(11-12): 12071230.

Shostack, G.L. (1977) Breaking free from product marketing, Journal of Marketing, 41(2): $77-82$.

Steenkamp, J.-B. E. M. and van Trijp, H. C. M. (1991) The use of LISREL in validating marketing constructs, International Journal of Research in Marketing, 8(4): 283-299. 
Taijfel, H. and Turner, J.C. (1979) In Austin, W. G. and Worchel, S., eds., The Social Psychology of Intergroup Relations, Monterey, CA: Brooks/Cole, pp. 7-24.

Turner, J.C., P.J. Oakes, S.A. Haslam and C.A. McGarty (1994) Self and collective: cognition and social context. Personality and Social Psychology Bulletin, 20: 454463.

Vargo, S.L. and Lusch, R.F. (2008) Service-dominant logic: continuing the evolution. Journal of the Academy of Marketing Science, 36(1): 1-10.

Yoo, B., Donthu, N. and Lee, S. (2000) An Examination of Selected Marketing Mix Elements and Brand Equity. Journal of the Academy of Marketing Science, 28(2): $195-211$. 
Figure 1. Conceptual model

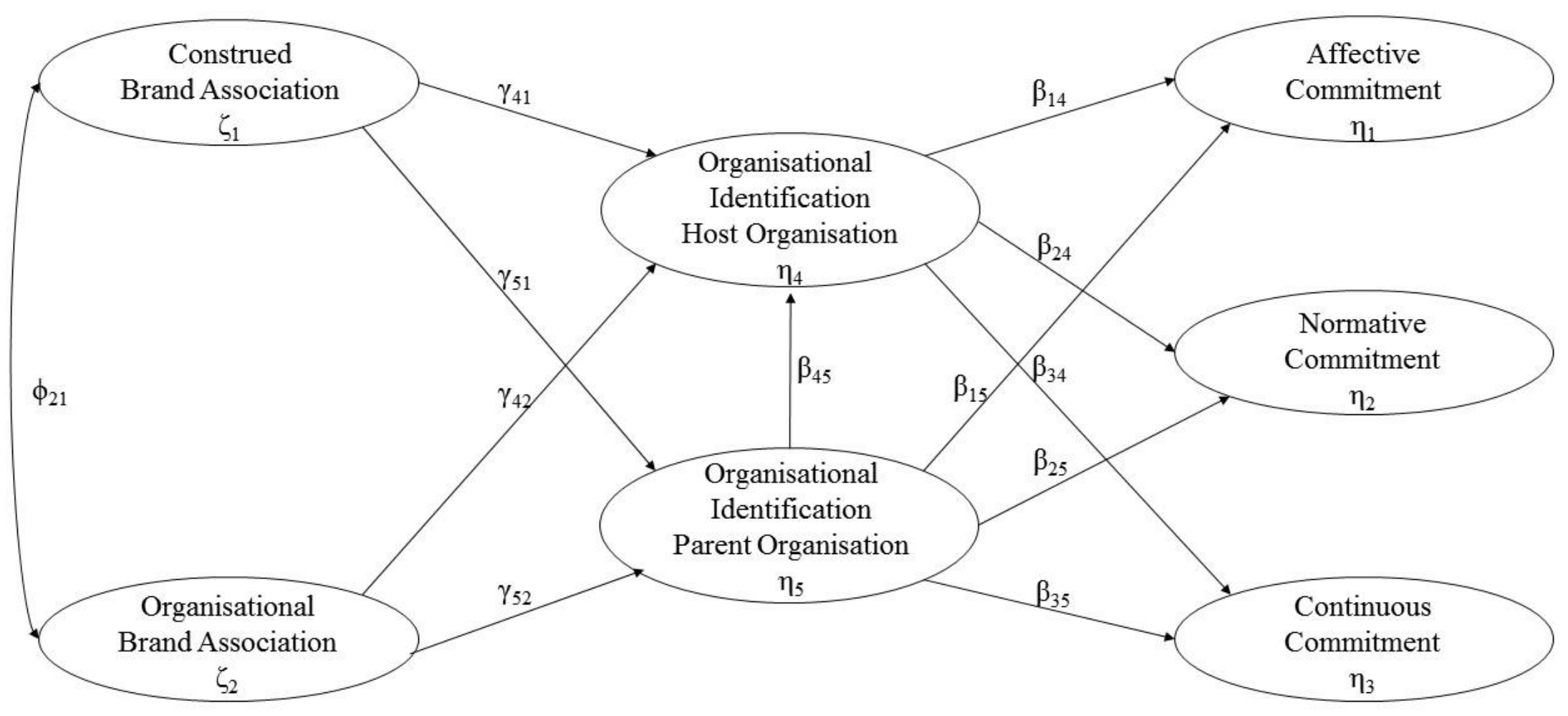


Table 1. Demographic information

\begin{tabular}{|l|l|l|l|}
\hline S/N & Items & Frequency & Percentage \\
\hline 1 & Gender & & \\
& & 103 & 70.1 \\
& Male & 43 & 29.3 \\
\hline 2 & Female & & \\
& Age & 3 & \\
& Under 20 & 35 & 2.2 \\
& $21-30$ & 44 & 26.1 \\
& $31-40$ & 36 & 32.8 \\
& $41-50$ & 16 & 26.9 \\
& Over 50 & & 11.9 \\
\hline 3 & Tenure & 31 & \\
& & 42 & 21.4 \\
& $0-4$ years & 26 & 29.0 \\
& 5-9 years & 27 & 17.9 \\
& $10-14$ years & 19 & 18.6 \\
& 15-24 years & & 13.1 \\
\hline
\end{tabular}


Table 2. Measurement model results

\begin{tabular}{|c|c|c|c|c|}
\hline Variable & Item & $\begin{array}{c}\text { Factor } \\
\text { loading }\end{array}$ & AVE & $\mathrm{CR}$ \\
\hline \multirow[t]{6}{*}{ Affective Commitment } & $\mathrm{AC} 1$ & 0.65 & 0.69 & 0.93 \\
\hline & AC4 & 0.79 & & \\
\hline & AC5 & 0.88 & & \\
\hline & AC6 & 0.92 & & \\
\hline & AC7 & 0.87 & & \\
\hline & AC8 & 0.83 & & \\
\hline \multirow[t]{6}{*}{ Normative commitment } & $\mathrm{NC1}$ & 0.47 & 0.52 & 0.81 \\
\hline & NC2 & 0.72 & & \\
\hline & NC3 & 0.76 & & \\
\hline & $\mathrm{NC} 4$ & 0.88 & & \\
\hline & NC5 & 0.75 & & \\
\hline & NC6 & 0.62 & & \\
\hline \multirow[t]{4}{*}{ Continuance commitment } & $\mathrm{CC} 1$ & 0.56 & 0.51 & 0.86 \\
\hline & $\mathrm{CC} 3$ & 0.79 & & \\
\hline & $\mathrm{CC} 4$ & 0.85 & & \\
\hline & CC5 & 0.64 & & \\
\hline \multirow[t]{5}{*}{ Organisational identification: Host } & OIH1 & 0.75 & 0.62 & 0.89 \\
\hline & $\mathrm{OIH} 2$ & 0.82 & & \\
\hline & OIH3 & 0.74 & & \\
\hline & OIH4 & 0.81 & & \\
\hline & OIH5 & 0.81 & & \\
\hline \multirow[t]{3}{*}{ Organisational identification: Parent } & OIP1 & 0.95 & 0.68 & 0.86 \\
\hline & OIP2 & 0.83 & & \\
\hline & OIP6 & 0.67 & & \\
\hline \multirow[t]{3}{*}{ Construed brand associations } & CBA1 & 0.94 & 0.88 & 0.96 \\
\hline & CBA2 & 0.97 & & \\
\hline & CBA3 & 0.91 & & \\
\hline \multirow[t]{3}{*}{ Organisational brand associations } & OBA1 & 0.83 & 0.82 & 0.93 \\
\hline & OBA2 & 0.96 & & \\
\hline & OBA3 & 0.91 & & \\
\hline
\end{tabular}

Note: $\mathrm{AVE}=$ Average Variance Extracted; $\mathrm{CR}=$ Composite Reliability 
Table 3. Means, Standard Deviation, AVE, Inter-Correlations and Squared Correlations

\begin{tabular}{|c|c|c|c|c|c|c|c|c|c|}
\hline & Means & SD & 1. & 2. & 3. & 4. & 5. & 6. & 7. \\
\hline 1. Affective Commitment & 4.35 & 1.55 & .69 & .00 & .40 & .57 & .06 & .17 & .30 \\
\hline 2. Continuance Commitment & 4.96 & 1.51 & .04 & .52 & .04 & .01 & .04 & .00 & .00 \\
\hline 3. Normative Commitment & 3.62 & 1.31 & .63 & .21 & .51 & .23 & .18 & .07 & .14 \\
\hline 4. Organisational Identification, Host & 4.57 & 1.39 & .75 & .11 & .48 & .62 & .12 & .24 & .36 \\
\hline 5. Organisational Identification, Parent & 2.28 & 1.27 & .24 & .20 & .43 & .34 & .68 & .00 & .00 \\
\hline 6. Construed Brand Association & 5.75 & 1.03 & .42 & .07 & .27 & .49 & .05 & .88 & .46 \\
\hline 7. Organisational Brand Associations & 5.49 & 1.19 & .54 & .03 & .38 & .60 & .06 & .68 & .82 \\
\hline
\end{tabular}

Notes: $\mathrm{N}=145$; AVE on the diagonal in bold; inter-correlations below the diagonal and squared correlations above the diagonal 
Table 4. Summary of structural model and hypothesis testing

\begin{tabular}{|c|c|c|c|c|}
\hline Hypothesis & Structural model relationship & $\begin{array}{l}\text { Standardised } \\
\text { estimate }\end{array}$ & t-value & $\begin{array}{l}\text { Relationship } \\
\text { supported }\end{array}$ \\
\hline H1 & Host organisational identification $\rightarrow$ Affective commitment $\left(\beta_{14}\right)$ & $0.79 * * *$ & 8.05 & Yes \\
\hline H1 & Host organisational identification $\rightarrow$ Continuance commitment $\left(\beta_{24}\right)$ & 0.04 & 0.41 & No \\
\hline H1 & Host organisational identification $\rightarrow$ Normative commitment $\left(\beta_{34}\right)$ & $0.27 * * *$ & 3.90 & Yes \\
\hline H1 & Parent organisational identification $\rightarrow$ Affective commitment $\left(\beta_{15}\right)$ & 0.03 & 0.24 & No \\
\hline $\mathrm{H} 1$ & Parent organisational identification $\rightarrow$ Continuance commitment $\left(\beta_{25}\right)$ & $0.19 *$ & 1.85 & Yes \\
\hline H1 & Parent organisational identification $\rightarrow$ Normative commitment $\left(\beta_{35}\right)$ & $0.27 * *$ & 2.87 & No \\
\hline $\mathrm{H} 2$ & Construed brand associations $\rightarrow$ Host organisational identification $\left(\gamma_{41}\right)$ & $0.15^{*}$ & 1.66 & Yes \\
\hline $\mathrm{H} 2$ & Construed brand associations $\rightarrow$ Parent organisational identification $\left(\gamma_{51}\right)$ & 0.01 & 0.07 & No \\
\hline $\mathrm{H} 2$ & Organisational brand associations $\rightarrow$ Host organisational identification $\left(\gamma_{42}\right)$ & $0.50 * * *$ & 4.68 & Yes \\
\hline $\mathrm{H} 2$ & Organisational brand associations $\rightarrow$ Parent organisational identification $\left(\gamma_{52}\right)$ & 0.06 & 0.46 & No \\
\hline H3 & Parent organisational identification $\rightarrow$ Host organisational identification $\left(\beta_{45}\right)$ & $0.31 * * *$ & 4.10 & Yes \\
\hline
\end{tabular}

Note: 1-tailed t-test, * Significant at .05 level; ** Significant at .01 level; *** Significant at .0001 level 